University of Nebraska - Lincoln

DigitalCommons@University of Nebraska - Lincoln

On the importance of stratigraphic control for vertebrate fossil sites in Channel Islands National Park, California, USA: Examples from new Mammuthus finds on San Miguel Island

Jeffrey S. Pigati

Daniel R. Muhs

John P. McGeehin

Follow this and additional works at: https://digitalcommons.unl.edu/usgsstaffpub

Part of the Geology Commons, Oceanography and Atmospheric Sciences and Meteorology Commons, Other Earth Sciences Commons, and the Other Environmental Sciences Commons

This Article is brought to you for free and open access by the US Geological Survey at DigitalCommons@University of Nebraska - Lincoln. It has been accepted for inclusion in USGS Staff -- Published Research by an authorized administrator of DigitalCommons@University of Nebraska - Lincoln. 


\title{
On the importance of stratigraphic control for vertebrate fossil sites in Channel Islands National Park, California, USA: Examples from new Mammuthus finds on San Miguel Island
}

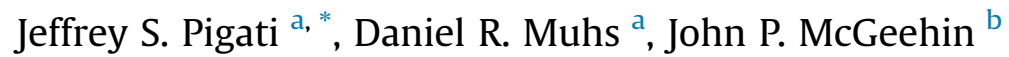 \\ ${ }^{a}$ U.S. Geological Survey, Denver Federal Center, Box 25046, MS-980, Denver, CO, 80225, USA \\ ${ }^{\mathrm{b}}$ U.S. Geological Survey, 12201 Sunrise Valley Drive, MS-926A, Reston, VA, 20192, USA
}

\section{A R T I C L E I N F O}

\section{Article history:}

Available online 28 September 2016

\section{Keywords:}

Mammoths

San Miguel Island

Stratigraphy

Radiocarbon dating

California Channel Islands

Site documentation

\begin{abstract}
A B S T R A C T
Quaternary vertebrate fossils, most notably mammoth remains, are relatively common on the northern Channel Islands of California. Well-preserved cranial, dental, and appendicular elements of Mammuthus exilis (pygmy mammoth) and Mammuthus columbi (Columbian mammoth) have been recovered from hundreds of localities on the islands during the past half-century or more. Despite this paleontological wealth, the geologic context of the fossils is described in the published literature only briefly or not at all, which has hampered the interpretation of associated ${ }^{14} \mathrm{C}$ ages and reconstruction of past environmental conditions. We recently discovered a partial tusk, several large bones, and a tooth enamel plate (all likely mammoth) at two sites on the northwest flank of San Miguel Island, California. At both localities, we documented the stratigraphic context of the fossils, described the host sediments in detail, and collected charcoal and terrestrial gastropod shells for radiocarbon dating. The resulting ${ }^{14} \mathrm{C}$ ages indicate that the mammoths were present on San Miguel Island between $\sim 20$ and $17 \mathrm{ka}$ as well as between 14 and $13 \mathrm{ka}$ (thousands of calibrated ${ }^{14} \mathrm{C}$ years before present), similar to other mammoth sites on San Miguel, Santa Cruz, and Santa Rosa Islands. In addition to documenting the geologic context and ages of the fossils, we present a series of protocols for documenting and reporting geologic and stratigraphic information at fossil sites on the California Channel Islands in general, and in Channel Islands National Park in particular, so that pertinent information is collected prior to excavation of vertebrate materials, thus maximizing their scientific value.
\end{abstract}

Published by Elsevier Ltd.

\section{Introduction}

Mammoths (genus Mammuthus) first appear in the fossil record during the early Pliocene ( $5-4 \mathrm{Ma}$ ) in southern and eastern Africa (Maglio, 1973; Kalb et al., 1996) and later in Europe, during the interval 3.5-2.5 Ma (Lister et al., 2005). Mammuthus expanded its range dramatically in the early Pleistocene, eventually covering much of Eurasia as the proboscideans became adapted to cool climates. This allowed them first to reach extreme northern Asia and Beringia, and then cross the land bridge into North America (Lister and Bahn, 2007). By 2.2-1.8 Ma, mammoths had expanded across North America as far south and east as Florida (Webb et al., 1989;

\footnotetext{
* Corresponding author.

E-mail address: jpigati@usgs.gov (J.S. Pigati).
}

Webb and Dudley, 1995; Muhs et al., 2015), which suggests that they had colonized most of the continent by that time.

At least four, and as many as five, distinct species of Mammuthus are currently recognized in the Pleistocene record of North America, including $M$. meridionalis, $M$. primigenius, $M$. columbi, and M. exilis, and perhaps M. trogontherii (Agenbroad, 1984, 2005; Lister and Sher, 2015). In the southwestern United States, mammoths reached southern California by 1.4-1.2 Ma, where the remains of $M$. meridionalis dating to this time period have been found in AnzaBorrego Desert State Park (McDaniel and Jefferson, 2006). Columbian mammoths (M. columbi) appear in this area at about the same time ( 1.1 Ma; McDaniel and Jefferson, 2006) and are the most common species found in late Pleistocene sediments on the southern California mainland (Stock and Harris, 1930; Agenbroad, 1984; Springer et al., 2010).

Mammoths inhabited the Channel Islands beginning at least $\sim 80 \mathrm{ka}$ and possibly as early as $\sim 150$ ka or even $\sim 250$ ka based on the 
presence of a pygmy mammoth ( $M$. exilis) tusk in a marine terrace on Santa Rosa Island that dates to Marine Oxygen Isotope Stage (MIS) 5a (Muhs et al., 2015). Pygmy mammoths evolved on the islands from Columbian mammoths, which likely swam across the Santa Barbara Channel during glacial period(s) when sea level was low and the distance between the islands and the mainland was relatively short (Johnson, 1978; Wenner and Johnson, 1980; Muhs et al., 2015). Although Columbian mammoths are considered to be the original island mammoths (Johnson, 1978, 1981; Madden, 1981; Roth, 1993) and served as ancestral stock to the pygmies (Agenbroad, 2001), fossils of pygmy mammoths are far more common than those of their ancestors, by a ratio of roughly 10 to 3 (Agenbroad, 2012).

Historically, mammoth fossils were first identified on the California Channel Islands during the Coast and Geodetic Survey of 1856 and reported in the scientific literature initially by Stearns (1873). Half a century later, Stock and Furlong (1935) formally designated the pygmy mammoth as a new species, Mammuthus exilis, which is unique to the islands. Following their study, little work was done on the island mammoths until the arrival of Phil Orr of the Santa Barbara Museum of Natural History in the mid-1950s. Although Orr's primary focus was archeology, he recognized that mammoth bones were plentiful in late Pleistocene sediments and hypothesized that the earliest human occupants of the islands may have interacted with mammoths prior to their extinction (Orr, 1956a, 1968; Orr and Berger, 1966). Although this hypothesis is still under debate Orr's work inspired a series of later studies, most notably by Larry Agenbroad (e.g., Agenbroad, 1984; 1998; 2001;
2003; 2005; 2012; Agenbroad et al., 2005) and Don Johnson (Johnson, 1972, 1981, 1978; Johnson et al., 1980). To date, nearly 400 different localities containing mammoth fossils-most of which are located on Santa Rosa Island-have been documented on the Channel Islands (Justin Wilkins, written comm., 2015). Prospecting and monitoring activities in Channel Islands National Park continue today under the purview of the National Park Service (NPS).

\subsection{Previous documentation at mammoth sites on the islands}

The California Channel Islands represent a spectacular natural laboratory for studies focusing on evolution and dwarfism, the timing and causes of elephant immigration from the mainland, responses of endemic flora and fauna to past episodes of climate change, and the possible interaction between humans and Pleistocene megafauna. Such studies involve the paleontological resources of the islands and it is therefore imperative that the geologic and stratigraphic context of the fossils are documented in detail and disseminated to the scientific community.

Little is known about the location of mammoth fossils that were removed from the islands prior to the 1950s. Documentation improved during Orr's tenure, as he usually stated the name of the canyon or general area where the specimens were found and occasionally reported latitude and longitude. Subsequent researchers followed suit, either through marking the site locations on a map or including coordinates (Table 1). Today, site locations are routinely determined using handheld GPS devices.

Table 1

Summary of published radiocarbon ages associated with Mammuthus remains on the California Channel Islands.

\begin{tabular}{|c|c|c|c|c|c|c|c|c|c|}
\hline Island $^{1}$ & Lab\# & $\begin{array}{l}\text { Reported age } \\
\text { (in thousands } \\
\text { of }^{14} \mathrm{C} \text { yrs) }\end{array}$ & Taxa & Material dated & $\begin{array}{l}\text { Reported } \\
\text { latitude }\left({ }^{\circ} \mathrm{N}\right)\end{array}$ & $\begin{array}{l}\text { Reported } \\
\text { longitude }\left({ }^{\circ} \mathrm{W}\right)\end{array}$ & $\begin{array}{l}\text { Paired } \\
\text { date? }\end{array}$ & $\begin{array}{l}\text { Stratigraphic } \\
\text { context? }\end{array}$ & Original citation \\
\hline SRI & UCLA-705 & $8.00 \pm 0.25$ & M. exilis & $\begin{array}{l}\text { Bone collagen; same specimen } \\
\text { as L-290T; too young } \\
\text { (contamination) }\end{array}$ & $34^{\circ} 00^{\prime} 20^{\prime \prime}$ & $120^{\circ} 11^{\prime} 20^{\prime \prime}$ & Yes $^{4 a}$ & None & Berger et al. (1965) \\
\hline SRI & Beta-14660 & $10.70 \pm 0.09$ & M. exilis & Unknown & $\mathrm{N} / \mathrm{A}$ & $\mathrm{N} / \mathrm{A}$ & No & None & Agenbroad (2012) \\
\hline SRI & Beta-133594 & $11.01 \pm 0.07$ & M. exilis & $\begin{array}{l}\text { Charcoal in association with } \\
\text { vertebra of pygmy mammoth }\end{array}$ & \multicolumn{2}{|c|}{ "Garanon Canyon" } & Yes $^{4 b}$ & None & Agenbroad (2005) \\
\hline SRI & CAMS-71697 & $11.03 \pm 0.05$ & M. exilis & $\begin{array}{l}\text { Bone collagen; Stafford XAD } \\
\text { protocol; same stratigraphic } \\
\text { level as B-133594 }\end{array}$ & $\mathrm{N} / \mathrm{A}$ & $\mathrm{N} / \mathrm{A}$ & Yes $^{4 b}$ & None & Agenbroad (2005) \\
\hline SRI & UCLA-106 & $11.80 \pm 0.80$ & M. exilis & $\begin{array}{l}\text { Charcoal in direct contact with } \\
\text { pygmy mammoth bone }\end{array}$ & $34^{\circ} 59^{\prime} 00^{\prime \prime}$ & $120^{\circ} 10^{\prime} 00^{\prime \prime}$ & No & None & $\begin{array}{l}\text { Fergusson and } \\
\text { Libby (1962) }\end{array}$ \\
\hline SRI & Beta-279387 & $12.12 \pm 0.06$ & M. columbi & Unknown & $\mathrm{N} / \mathrm{A}$ & $\mathrm{N} / \mathrm{A}$ & No & None & Agenbroad (2012) \\
\hline SRI & Beta-131341 & $12.41 \pm 0.04$ & M. exilis & Unknown & $\mathrm{N} / \mathrm{A}$ & $\mathrm{N} / \mathrm{A}$ & No & None & Agenbroad (2012) \\
\hline SRI & L-290T & $12.50 \pm 0.25$ & M. exilis & $\begin{array}{l}\text { Charcoal from mammoth } \\
\text { bearing sediments }\end{array}$ & $34^{\circ} 00^{\prime} 20^{\prime \prime}$ & $120^{\circ} 11^{\prime} 20^{\prime \prime}$ & $\mathrm{Yes}^{4 a}$ & None & $\begin{array}{l}\text { Broecker and } \\
\text { Kulp (1957) }\end{array}$ \\
\hline SRI & UCIAMS-68006 & $12.55 \pm 0.05$ & M. columbi & Unknown & $\mathrm{N} / \mathrm{A}$ & $\mathrm{N} / \mathrm{A}$ & No & None & Agenbroad (2012) \\
\hline SRI & CAMS-24429 & $12.84 \pm 0.41$ & M. exilis & $\begin{array}{l}\text { Bone collagen from right femur; } \\
\text { Stafford XAD protocol; AMS }\end{array}$ & \multicolumn{2}{|c|}{ near Carrington Point } & No & "Dune sand" & $\begin{array}{l}\text { Agenbroad } \\
(1998,2003)^{5}\end{array}$ \\
\hline SRI & Beta-96610 & $13.77 \pm 0.06$ & M. exilis & $\begin{array}{l}\text { Charcoal in association with } \\
\text { mammoth remains; AMS }\end{array}$ & \multicolumn{2}{|l|}{ south coast } & No & None & $\begin{array}{l}\text { Agenbroad } \\
(1998,2003)^{5}\end{array}$ \\
\hline SRI & $\mathrm{L}-244$ & $15.82 \pm 0.28$ & M. exilis & $\begin{array}{l}\text { Partially charred and badly } \\
\text { decomposed wood from below } \\
\text { pygmy mammoth }\end{array}$ & $\mathrm{N} / \mathrm{A}$ & $\mathrm{N} / \mathrm{A}$ & No & None & $\begin{array}{l}\text { Broecker } \\
\text { et al. (1956) }\end{array}$ \\
\hline SRI & M-599 & $16.70 \pm 1.50$ & M. exilis & $\begin{array}{l}\text { Charcoal in association with } \\
\text { pygmy mammoth remains }\end{array}$ & $\mathrm{N} / \mathrm{A}$ & $\mathrm{N} / \mathrm{A}$ & No & None & $\begin{array}{l}\text { Crane and } \\
\text { Griffin (1958) }\end{array}$ \\
\hline SRI & Beta-131340 & $16.81 \pm 0.05$ & M. exilis & Unknown & $\mathrm{N} / \mathrm{A}$ & $\mathrm{N} / \mathrm{A}$ & No & None & Agenbroad (2012) \\
\hline SRI & Beta-278091 & $17.50 \pm 0.07$ & M. columbi & Unknown & $\mathrm{N} / \mathrm{A}$ & $\mathrm{N} / \mathrm{A}$ & No & None & Agenbroad (2012) \\
\hline SRI & Beta-92053 & $18.13 \pm 0.07$ & M. exilis? & $\begin{array}{l}\text { Charcoal in association with } \\
\text { mammoth remains }\end{array}$ & \multicolumn{2}{|c|}{ southwestern coast } & No & None & $\begin{array}{l}\text { Agenbroad } \\
(1998,2003)^{5}\end{array}$ \\
\hline SRI & Beta-85077 & $18.88 \pm 0.19$ & M. exilis? & $\begin{array}{l}\text { Charcoal in association with } \\
\text { mammoth remains }\end{array}$ & \multicolumn{2}{|l|}{ northern coast } & No & None & $\begin{array}{l}\text { Agenbroad } \\
(1998,2003)^{5}\end{array}$ \\
\hline SRI & CAMS-62265 & $26.68 \pm 0.33$ & M. exilis & Unknown & $\mathrm{N} / \mathrm{A}$ & $\mathrm{N} / \mathrm{A}$ & No & None & Agenbroad (2012) \\
\hline SRI & L-290R & $29.70 \pm 3.00$ & M. exilis & Charred mammoth bone & $\mathrm{N} / \mathrm{A}$ & $\mathrm{N} / \mathrm{A}$ & Yes $^{5}$ & None & $\begin{array}{l}\text { Broecker and } \\
\text { Kulp (1957) }\end{array}$ \\
\hline SRI & UCLA-1898 & $30.40 \pm 2.50$ & M. exilis & $\begin{array}{l}\text { Bone collagen from uncharred } \\
\text { bone; same stratigraphic level } \\
\text { as L-290R }\end{array}$ & $\mathrm{N} / \mathrm{A}$ & $\mathrm{N} / \mathrm{A}$ & Yes $^{4 c}$ & None & Bada et al. (1974) \\
\hline
\end{tabular}


Table 1 (continued)

\begin{tabular}{|c|c|c|c|c|c|c|c|c|c|}
\hline Island $^{1}$ & Lab\# & $\begin{array}{l}\text { Reported age }{ }^{2} \\
\text { (in thousands } \\
\text { of }^{14} \mathrm{C} \text { yrs) }\end{array}$ & Taxa & Material dated & $\begin{array}{l}\text { Reported } \\
\text { latitude }\left({ }^{\circ} \mathrm{N}\right)\end{array}$ & $\begin{array}{l}\text { Reported } \\
\text { longitude }\left({ }^{\circ} \mathrm{W}\right)\end{array}$ & $\begin{array}{l}\text { Paired } \\
\text { date? }\end{array}$ & $\begin{array}{l}\text { Stratigraphic } \\
\text { context? }\end{array}$ & Original citation \\
\hline SRI & Beta-133597 & $40.91 \pm 0.64$ & M. exilis & Unknown & $\mathrm{N} / \mathrm{A}$ & $\mathrm{N} / \mathrm{A}$ & No & None & Agenbroad (2012) \\
\hline SRI & Beta-133596 & $42.80 \pm 1.00$ & M. exilis & Unknown & $\mathrm{N} / \mathrm{A}$ & $\mathrm{N} / \mathrm{A}$ & No & None & Agenbroad (2012) \\
\hline SRI & CAMS-166111 & $40.91 \pm 0.55$ & Mammuthus sp. & $\begin{array}{l}\text { Terrestrial gastropod shells } \\
\text { (Helminthoglypta ayresiana) }\end{array}$ & $34^{\circ} 01.19^{\prime}$ & $120^{\circ} 05.51^{\prime}$ & No & Yes - detailed & Muhs et al. (2015) \\
\hline SRI & CAMS-166109 & $40.95 \pm 0.56$ & Mammuthus sp. & $\begin{array}{l}\text { Terrestrial gastropod shells } \\
\text { (Helminthoglypta ayresiana) }\end{array}$ & $34^{\circ} 01.19^{\prime}$ & $120^{\circ} 05.48^{\prime}$ & No & yes - detailed & Muhs et al. (2015) \\
\hline SRI & CAMS-166108 & $41.77 \pm 0.62$ & Mammuthus sp. & $\begin{array}{l}\text { Terrestrial gastropod shells } \\
\text { (Helminthoglypta ayresiana) }\end{array}$ & $34^{\circ} 01.19^{\prime}$ & $120^{\circ} 05.48^{\prime}$ & No & Yes - detailed & Muhs et al. (2015) \\
\hline SRI & CAMS- 166110 & $43.46 \pm 0.75$ & Mammuthus sp. & $\begin{array}{l}\text { Terrestrial gastropod shells } \\
\text { (Helminthoglypta ayresiana) }\end{array}$ & $34^{\circ} 01.19^{\prime}$ & $120^{\circ} 05.51^{\prime}$ & No & Yes - detailed & Muhs et al. (2015) \\
\hline SRI & CAMS-166112 & $46.20 \pm 1.10$ & Mammuthus sp. & $\begin{array}{l}\text { Terrestrial gastropod shells } \\
\text { (Helminthoglypta ayresiana) }\end{array}$ & $34^{\circ} 01.19^{\prime}$ & $120^{\circ} 05.51^{\prime}$ & No & Yes - detailed & Muhs et al. (2015) \\
\hline SRI & Beta-131342 & $>44.96$ & M. exilis & Unknown & $\mathrm{N} / \mathrm{A}$ & $\mathrm{N} / \mathrm{A}$ & No & None & Agenbroad (2012) \\
\hline SRI & Beta-94256 & $>47.11$ & M. exilis & $\begin{array}{l}\text { Charcoal in association with } \\
\text { mammoth remains; AMS }\end{array}$ & \multicolumn{2}{|c|}{ near Ford Point } & No & None & $\begin{array}{l}\text { Agenbroad } \\
(1998,2003)^{5}\end{array}$ \\
\hline SRI & Beta-85274 & $>47.99$ & M. exilis & $\begin{array}{l}\text { Charcoal presumably in } \\
\text { association with mammoth } \\
\text { remains (unclear) }\end{array}$ & $\mathrm{N} / \mathrm{A}$ & $\mathrm{N} / \mathrm{A}$ & No & None & Agenbroad (2003) \\
\hline SMI & ISGS-525 & $15.63 \pm 0.46^{3}$ & M. exilis & $\begin{array}{l}\text { Same sample as ISGS-518 but } \\
\text { leached with } 0.1 \mathrm{NaOH}\end{array}$ & $34^{\circ} 02^{\prime} 44^{\prime \prime}$ & $120^{\circ} 25^{\prime} 34^{\prime \prime}$ & $\mathrm{Yes}^{4 \mathrm{~d}}$ & None & $\begin{array}{l}\text { Liu and Coleman } \\
\text { (1981) }\end{array}$ \\
\hline SMI & ISGS-518 & $16.52 \pm 0.15$ & M. exilis & $\begin{array}{l}\text { Charcoal in direct association } \\
\text { with burned pygmy mammoth } \\
\text { bone }\end{array}$ & $34^{\circ} 02^{\prime} 44^{\prime \prime}$ & $120^{\circ} 25^{\prime} 34^{\prime \prime}$ & Yes $^{4 \mathrm{~d}}$ & None & $\begin{array}{l}\text { Liu and Coleman } \\
\text { (1981) }\end{array}$ \\
\hline SMI & ISGS-542 & $34.55 \pm 0.49$ & M. exilis & Unknown & $\mathrm{N} / \mathrm{A}$ & $\mathrm{N} / \mathrm{A}$ & No & None & Agenbroad (2012) \\
\hline $\mathrm{SCI}$ & AA-1268 & $10.29 \pm 0.10$ & Mammuthus sp. & $\begin{array}{l}\text { Wood in contact with } \\
\text { mammoth tusk }\end{array}$ & $\mathrm{N} / \mathrm{A}$ & $\mathrm{N} / \mathrm{A}$ & No & None & $\begin{array}{l}\text { Wenner et al. } \\
\text { (1991) }\end{array}$ \\
\hline
\end{tabular}

1 SRI = Santa Rosa Island; SMI = San Miguel Island; SCI = Santa Cruz Island.

2 Uncertainties are given at the $1 \sigma(68 \%)$ confidence level as originally reported.

${ }^{3}$ Age reported as $16.63 \pm 0.46{ }^{14} \mathrm{C}$ years by Wenner et al. (1991).

4 Paired ages are demarcated by matching superscript letters.

${ }^{5}$ The ${ }^{14} \mathrm{C}$ age and location information was originally provided in Agenbroad (1998). The technique used (AMS vs standard) and material dated was discussed in Agenbroad (2003).

Chronometric age control on specimens collected prior to the 1950s was not possible because the techniques that are in use today (radiocarbon, luminescence) simply did not exist. Orr obtained several radiocarbon $\left({ }^{14} \mathrm{C}\right)$ ages for island mammoth sites, including multiple localities on Santa Rosa Island (Orr, 1956b, 1960). The veracity of these ages is particularly impressive considering that they were obtained during the early days of ${ }^{14} \mathrm{C}$ dating. Since then, $34{ }^{14} \mathrm{C}$ ages related to mammoths on the Channel Islands have been published in the scientific literature, including four paired samples in which either multiple materials from the same stratigraphic interval (bone collagen, charcoal) or different components of the same sample of organic matter (humins, humic acids) were dated (Table 1). The use of paired ages is particularly powerful because it allows researchers to evaluate potential issues related to reworking, which makes apparent ${ }^{14} \mathrm{C}$ age interpretations of the host sediments too old, and chemical contamination, which usually results in ${ }^{14} \mathrm{C}$ ages that are anomalously young. Single ages are clearly better than no age control at all, but do not allow for such evaluations to take place.

With the exception of one recent study (Muhs et al., 2015), the sum total of information related to the geologic context of mammoth sites on the California Channel Islands that have been dated by ${ }^{14} \mathrm{C}$ consists of two words- "dune sand"-as described for the 1994 pygmy mammoth discovered on Santa Rosa Island (Agenbroad and Morris, 1999). Similarly, and again with the exception of Muhs et al. (2015), detailed stratigraphic information is not included in the published literature for any of the mammoth sites on the islands that have been dated by ${ }^{14} \mathrm{C}$ (Table 1 ).

The lack of geologic context and stratigraphic data for sites containing mammoth fossils from the Channel Islands is a problem because ${ }^{14} \mathrm{C}$ ages in isolation cannot be evaluated for their integrity, nor can broad paleoenvironmental reconstructions be made without contextual information. This paper addresses the need to codify and standardize documentation and reporting protocols in order to maximize the scientific value of fossils recovered from the islands in the future. A good illustration of this comes from a recent study on the diet of pygmy mammoths on Santa Rosa Island that has significant ecological implications (Semprebon et al., 2016). The study was done very carefully, but the specimens analyzed lack age and stratigraphic control. Such information would have strengthened the already important observations made by those authors.

Previous researchers have advanced our understanding of the flora, fauna, archaeology, and geology of the islands tremendously, and it is not our intent here to dismiss or disparage their work. Nevertheless, innumerable fossils collected over the years from the Channel Islands that lack location and stratigraphic data serve as a testament to the need for establishing proper documentation and reporting protocols prior to their recovery. Here, we propose sitespecific protocols for documenting the geologic context, stratigraphy, and radiocarbon ages using two newly discovered mammoth localities on San Miguel Island, Channel Islands National Park, California. The fossils were discovered in 2014-15 by the authors and were subsequently excavated by National Park Service personnel. We use these discoveries as case studies to demonstrate the level of detail recommended to document fossil sites on the islands in the future.

\section{Study sites}

San Miguel Island is the westernmost of the eight California Channel Islands, and is one of five islands that make up Channel Islands National Park. It is located a little more than $40 \mathrm{~km}$ from the mainland and covers an area of $\sim 37.7 \mathrm{~km}^{2}$, rising some $250 \mathrm{~m}$ above sea level. During glacial times when sea level was significantly 
lower than today, San Miguel was the westernmost part of a large island referred to as Santarosae (Orr, 1968). Rising sea level at the end of the Pleistocene split Santarosae into four distinct islands (San Miguel, Santa Rosa, Santa Cruz, and Anacapa) with San Miguel separating from the others at $\sim 9.5$ ka (Clark et al., 2014; ReederMyers et al., 2015).

Today, nearly two-thirds of San Miguel Island is covered by Holocene and historical dune sand that sits on Mesozoic and Neogene sedimentary rocks (mostly sandstone and shale), Miocene volcanics, and Quaternary eolianite (Dibblee, 2001). The eolianite and uncemented dune sand exhibit a distinct white color because the sand is composed largely of carbonate marine skeletal fragments that were exposed on what is now the insular shelf during periods of low sea level (Johnson, 1977; Muhs et al., 2009). The dunes were mobilized in the late 19th and 20th centuries when the ground surface was stripped of vegetation during droughts and by extensive grazing (Johnson et al., 1980; Erlandson et al., 2004b). Following the end of sheep ranching on the island a half century ago, expansion of both native and invasive vegetation and the development of biological soil crusts began to stabilize the dunes in many parts of the island (Zellman, 2015).

Running Springs is located on the northwestern flank of San Miguel Island and consists of several relatively large, freshwater springs that flow throughout the year (RS in Fig. 1). At an elevation of $\sim 70 \mathrm{~m}$, impermeable bedrock and cemented eolianite keep groundwater near the surface where the springs support an array of dense, hydrophilic vegetation not found elsewhere on the island (note the distinct green colors in Fig. 1c). Tufa (calcium carbonate; $\mathrm{CaCO}_{3}$ ) is actively forming where the springs emerge. Based on the presence of multiple generations of cemented tufa, the $\mathrm{CaCO}_{3}-$ saturated spring waters probably flowed here for much of the Quaternary, attracting both mammoths and humans alike to this part of the island.

The Running Springs area has been the focus of archeological investigations, including the discovery of a 9500-year-old shell midden (Erlandson et al., 2004a), as well as previous prospecting expeditions for vertebrate fossils. Members of a 1998 expedition were tantalizingly close to a buried tusk that was exposed in subsequent years by natural erosion and discovered by one of us (DRM) in 2014 (Fig. 2). Cyclic prospecting is an important component of research on the California Channel Islands because weathering and erosion are constantly exposing, and ultimately transporting away, vertebrate fossils.

The mammoth tusk locality, which we refer to informally as the East Running Springs (ERS) site is located at $34.04776^{\circ} \mathrm{N}$, $120.42339^{\circ} \mathrm{W}$ (WGS-84). The tusk is hosted by colluvium that
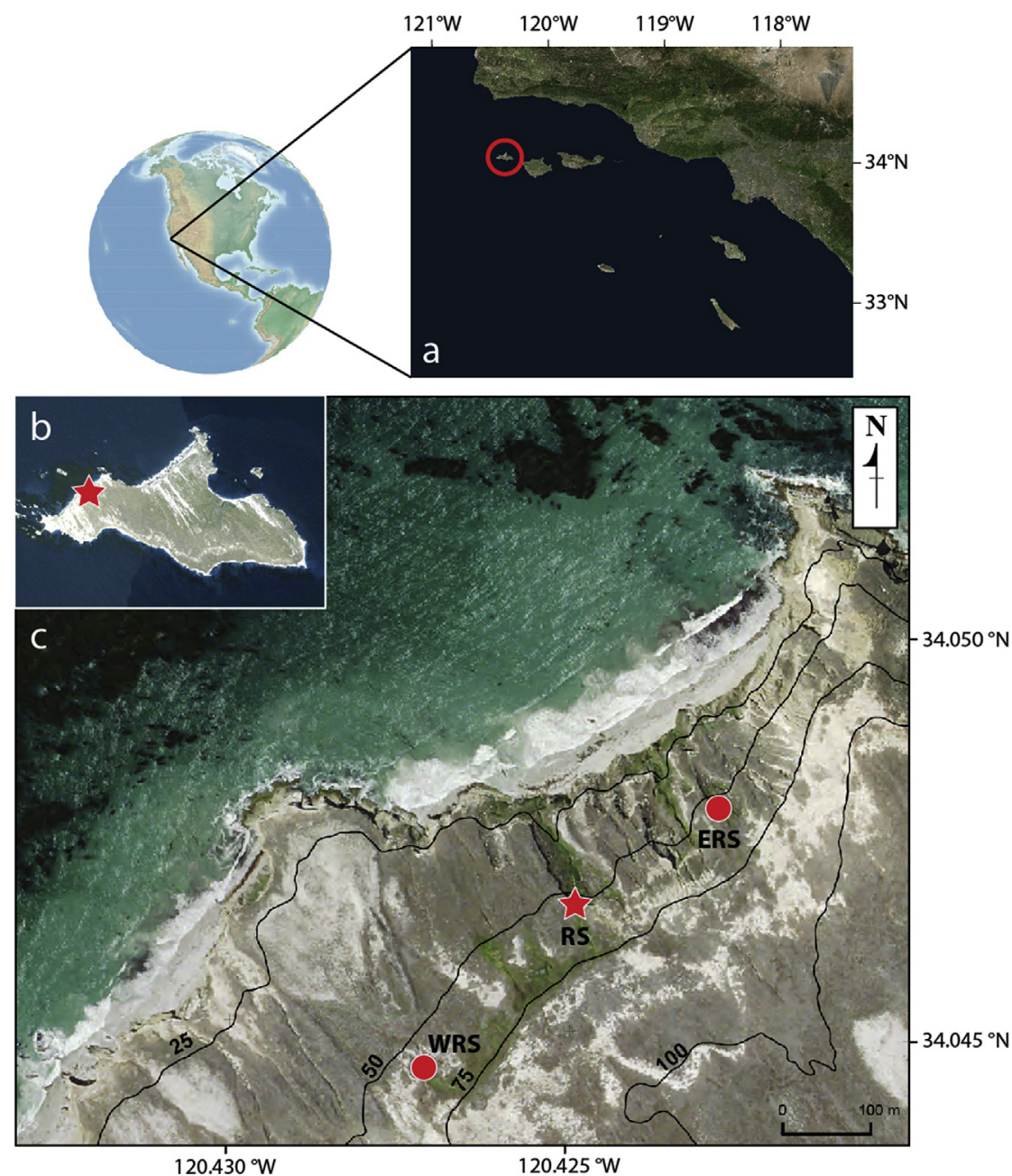

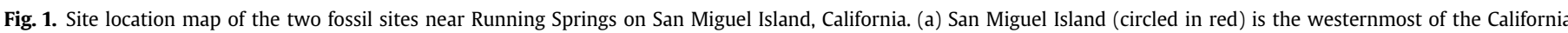

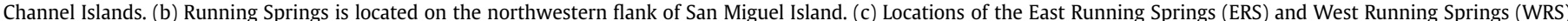

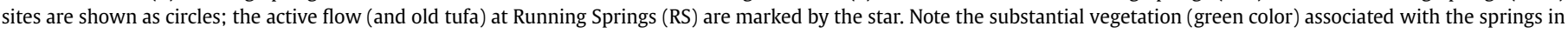
an otherwise arid landscape. (For interpretation of the references to colour in this figure legend, the reader is referred to the web version of this article.) 

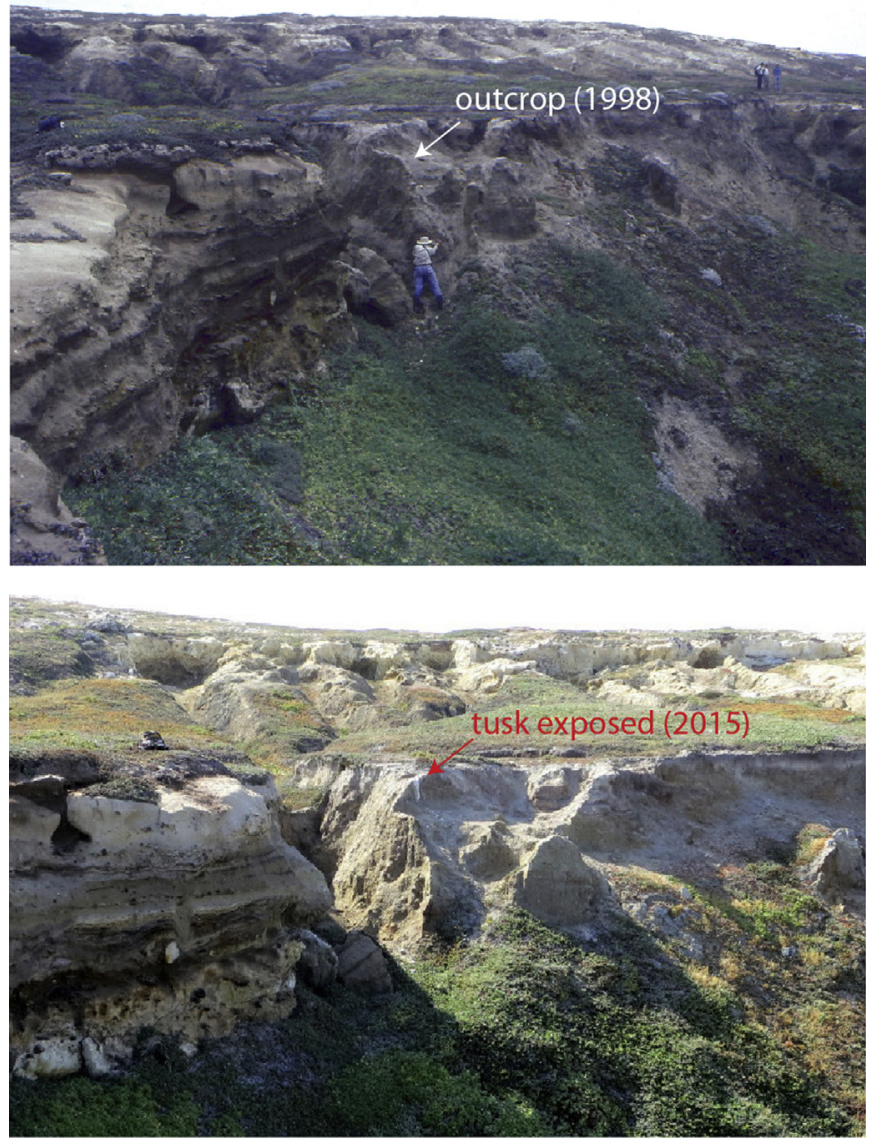

Fig. 2. Top panel. Photograph of the East Running Springs fossil site in 1998 before erosion exposed the tusk. Bottom panel. The tusk as it was exposed in outcrop in 2015. Continuous erosion requires cyclic prospecting for newly exposed fossils on the California Channel Islands. The 1998 photograph is courtesy of Don and Diana Johnson; the 2015 photograph was taken by the authors.

originates from older unconsolidated sediment and eolianite that crop out upslope of the ERS locality (Fig. 3a). Here, several large post-cranial bones attributable to mammoth are exposed $\sim 30-50 \mathrm{~cm}$ below the ground surface in silts and sands that overlie poorly sorted colluvial sands and gravels (Fig. $3 b-c$ ). Interbedded with the colluvial materials are older fine-grained sediments that contain a partial tusk $(\sim 40 \mathrm{~cm}$ long and $\sim 12 \mathrm{~cm}$ in diameter) (Fig. 3d-e). A second site, called the West Running Springs (WRS) site, was found nearby at $34.04536^{\circ} \mathrm{N}$, $120.42668^{\circ} \mathrm{W}$ (WGS-84). This site contains a $10 \mathrm{~cm} \times 7 \mathrm{~cm}$ tooth enamel plate (also likely mammoth) and a bone fragment that are both hosted in silts, sands, and gravels exposed along a small, eastfacing arroyo wall (Fig. $3 \mathrm{f}-\mathrm{g}$ ). Both fossil sites are positioned at essentially the same elevation $(\sim 50 \mathrm{~m}$ asl $)$ as the active, tufaforming springs.

\section{Methods}

Standard geological and stratigraphic practices were employed during the course of the study. Both sites at Running Springs were photo-documented and their positions recorded with a handheld GPS unit. All physical samples and digital data reside at the U.S. Geological Survey in Denver, Colorado. Samples for radiocarbon dating and geochemical analyses were collected under NPS permit \#CHIS-2007-SCI-0013.
Radiocarbon $\left({ }^{14} \mathrm{C}\right)$ dating of charcoal (charred vascular plants) and terrestrial gastropod shells (Helminthoglypta ayresiana) was used to establish the chronologic framework for the two fossil sites. Charcoal samples were subjected to the standard acid-baseacid treatment and then combusted in a sealed quartz tube in the presence of cupric oxide and silver. The resulting $\mathrm{CO}_{2}$ was split into two aliquots. One aliquot was converted to graphite using an iron catalyst and the standard hydrogen reduction process and submitted to the Center for Accelerator Mass Spectrometry (CAMS) at Lawrence Livermore National Laboratory for ${ }^{14} \mathrm{C}$ analysis. The second aliquot was submitted to the University of California, Davis Stable Isotope Laboratory for $\delta^{13} \mathrm{C}$ analysis in order to correct the measured ${ }^{14} \mathrm{C}$ activity for isotopic fractionation.

Gastropod shells were placed in a beaker of ASTM Type 1, 18.2 $\mathrm{M} \Omega$ (ultrapure) water and subjected to an ultrasonic bath until the shells were visibly clean. In most cases, shells were treated with $\mathrm{H}_{2} \mathrm{O}_{2}$ and then selectively dissolved or etched briefly with dilute $\mathrm{HCl}$ to remove secondary carbonate (dust) from primary shell material. The etched shells were washed repeatedly in ultrapure water and dried in an oven overnight at $70^{\circ} \mathrm{C}$. The shells were then broken and examined under a dissecting microscope to ensure that the interior whorls were free of secondary carbonate and detritus. We selected several shells at random for X-ray diffraction (XRD) analysis to verify that only primary shell aragonite remained prior to preparation for ${ }^{14} \mathrm{C}$ analysis. None of the fossil shells that we analyzed contained measurable quantities of calcite.

Clean shell carbonate was converted to $\mathrm{CO}_{2}$ using ACS reagent grade $85 \% \mathrm{H}_{3} \mathrm{PO}_{4}$ under vacuum at $50{ }^{\circ} \mathrm{C}$ until the reaction was visibly complete $(\sim 1 \mathrm{~h})$. The resulting $\mathrm{CO}_{2}$ was processed in the same manner as the charcoal samples. The magnitude of the "limestone problem" (Goodfriend and Stipp, 1983) for the shells of $H$. ayresiana was determined by comparing measured $\Delta^{14} \mathrm{C}$ values of modern shells and modeled $\Delta^{14} \mathrm{C}$ values of the gastropods' diet following methods described in Pigati et al. (2010). The average limestone effect was used to correct the measured ${ }^{14} \mathrm{C}$ ages of the shells prior to calibration; all associated uncertainties were propagated in quadrature.

Finally, the ${ }^{14} \mathrm{C}$ ages (corrected ages for the gastropod shells, standard ages for the charcoal) were calibrated using the IntCal13 dataset and the CALIB 7.1.html calibration program (Stuiver and Reimer, 1993; Reimer et al., 2013). Ages are presented in calibrated ${ }^{14} \mathrm{C}$ years $\mathrm{BP}(\mathrm{ka}=$ thousands of years; $\mathrm{BP}=$ Before Present; $0 \mathrm{yr} \mathrm{BP}=1950$ A.D.) and uncertainties are given at the $95 \%(2 \sigma)$ confidence level.

\section{Results}

\subsection{Stratigraphy}

At least five distinct stratigraphic units, designated as strata A-E (from oldest to youngest), are present at the ERS site and are $\sim 4 \mathrm{~m}$ thick collectively (Fig. 4). Stratum A is $\sim 1.5 \mathrm{~m}$ thick and is exposed at the base of the gully. It consists of heavily weathered, oxidized sandstone cobbles (3-5 $\mathrm{cm}$ in diameter) and reworked tufa gravels in a silty sand matrix. Many of the clasts have weathered to a brownish-orange color. This stratum exhibits pronounced bedding planes that are a few centimeters thick and is separated from the overlying sediments by an irregular, wavy contact. Stratum B ranges from 0.5 to $1.0 \mathrm{~m}$ thick and is composed of light brown silts and sands with isolated gravels and occasional terrestrial gastropod shells. This stratum is massive and fairly well sorted with the exception of the isolated clasts. The contact between strata B and C is also wavy but clear. Stratum $C$ is $\sim 1 \mathrm{~m}$ 

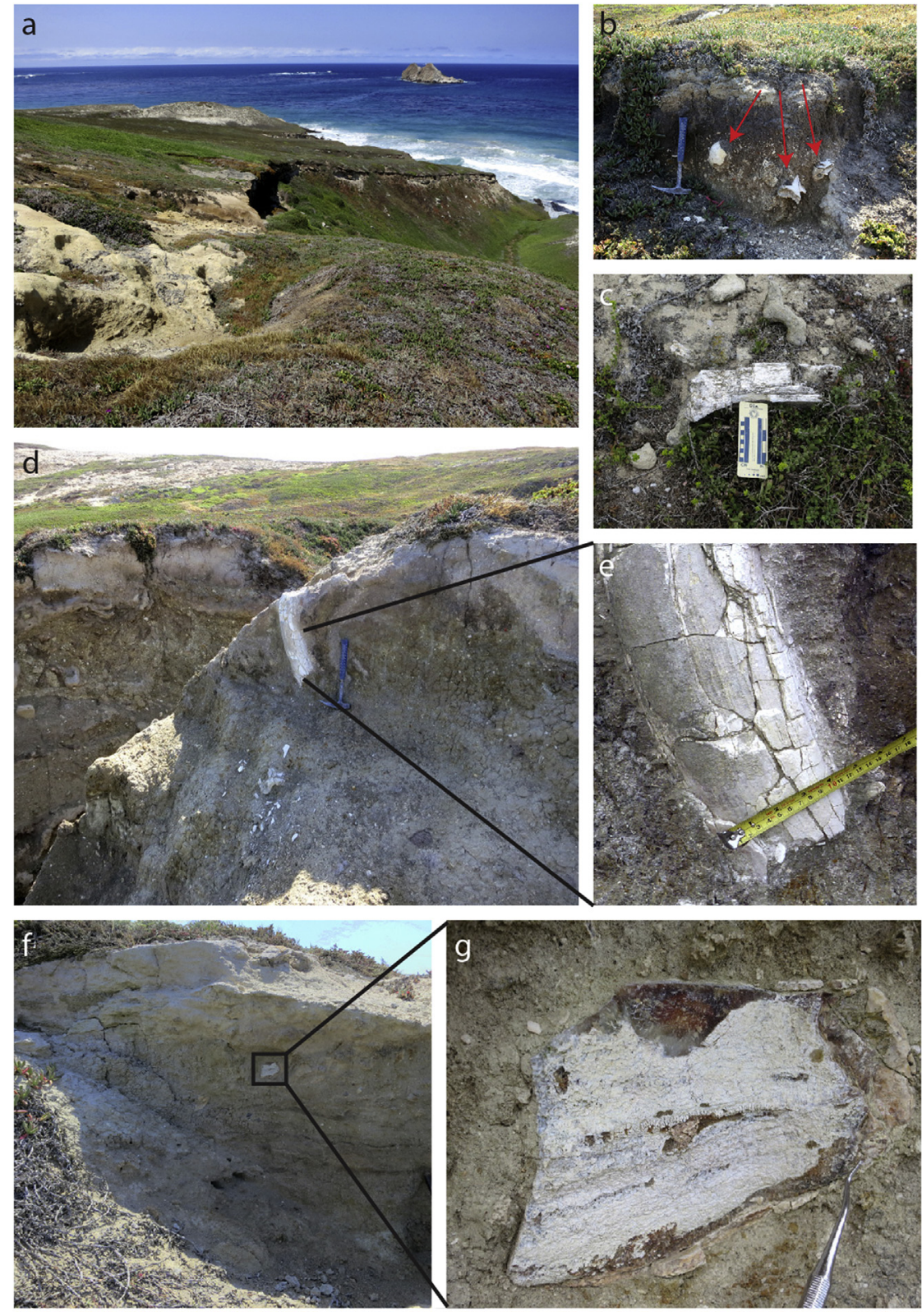

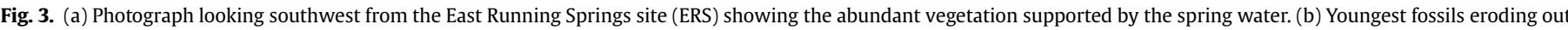

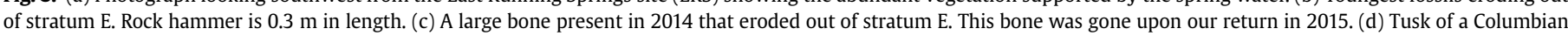

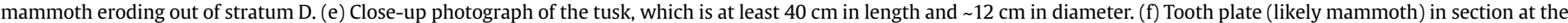
West Running Springs site (WRS). (g) Close-up photograph of the tooth plate, which is $10 \mathrm{~cm} \times 7 \mathrm{~cm}$. Photographs taken by the authors.

thick and consists of poorly sorted colluvium that contains abundant angular to subangular pebbles, cobbles, and occasional boulders in a gray sand matrix. We did not observe any in situ gastropod shells within this stratum, although there are a few pieces of dispersed charcoal present. This stratum appears to have been formed by a series of localized mass wasting events that transported eolianite fragments and sandstone pebbles and cobbles down from nearby outcrops. The events likely occurred over a short period of time given the stratigraphic expression of the sediments (in places, stratum $C$ is matrix supported) and the lack of intervening paleosols, unconformities, or other evidence of depositional hiatuses (Fig. 4). Stratum D is up to $\sim 0.5 \mathrm{~m}$ thick and consists of massive, well-sorted, gray silts and sands that contain abundant gastropod shells. Abundant reworked tufa clasts are present at the base of this stratum, which can be traced upgradient for several tens of meters. Notably, the tusk at the ERS site was located within stratum D (Fig. $3 \mathrm{~d}-\mathrm{e}$ ). Finally, stratum $\mathrm{E}$ is also $\sim 0.5 \mathrm{~m}$ thick and consists of massive, well-sorted gray silts and sands. It exhibits a second layer of reworked tufa at its base. Several large bones (distal appendicular material) attributable to mammoth were found in stratum E (Fig. $3 \mathrm{~b}-\mathrm{c}$ ). The sedimentary sequence is capped by a $\sim 30$-cm-thick, modern soil with an A/C profile.

Sediments exposed at the WRS site are $\sim 1.2 \mathrm{~m}$ thick collectively and consist of poorly sorted, massive sands and fine gravels that are interbedded with thin $(<1 \mathrm{~cm})$ layers of organic-rich silts and sands (Fig. 5). The sands and gravels are capped by a layer of reworked tufa clasts and carbonate-rich silts and sands. The tooth enamel 


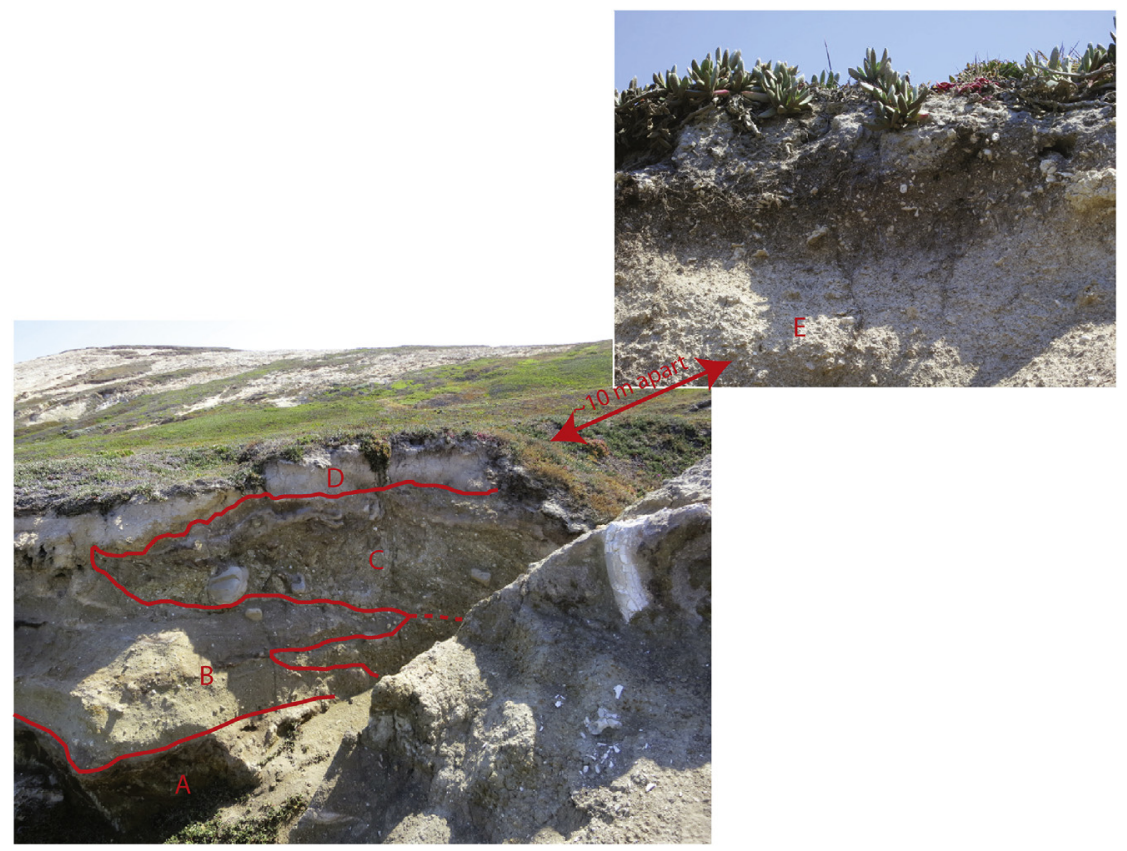

Fig. 4. Photographs of the Eastern Running Springs site (ERS) along with the identified strata (A-E). Note that the tusk is eroding out of stratum D, which was deposited at $\sim 20$ ka. Photographs taken by the authors.

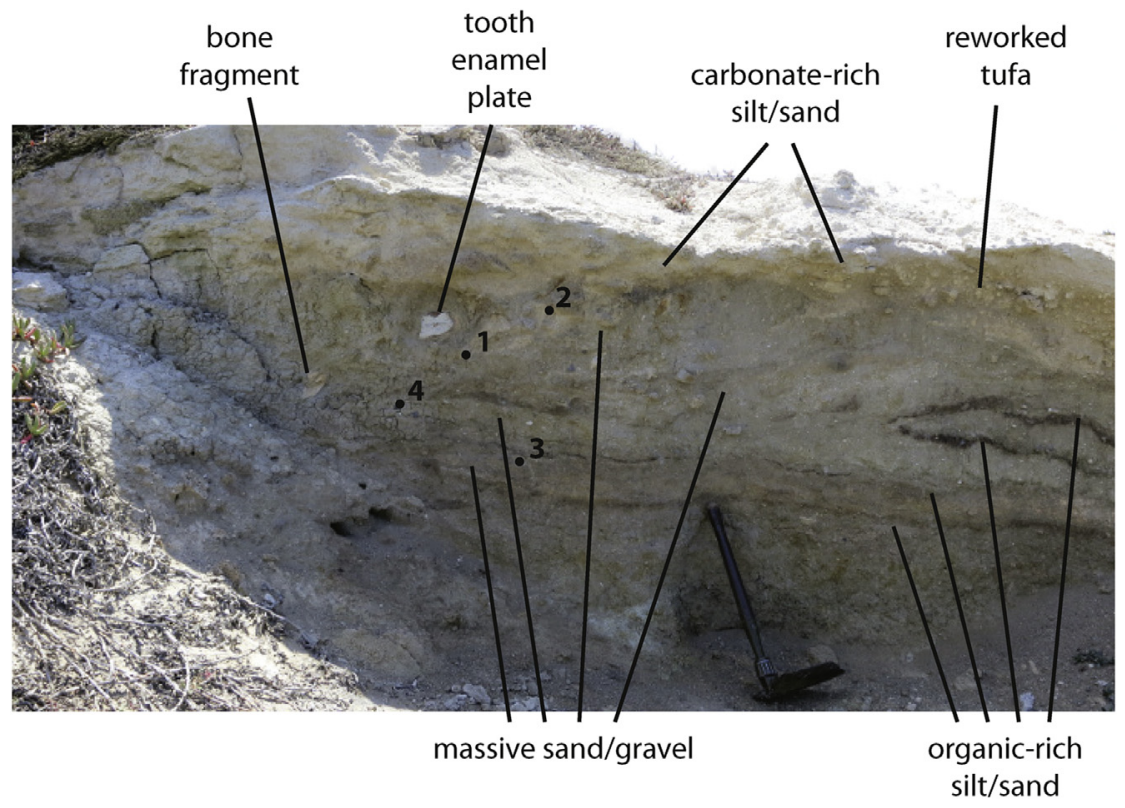

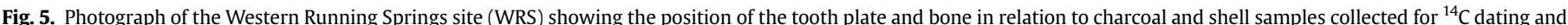

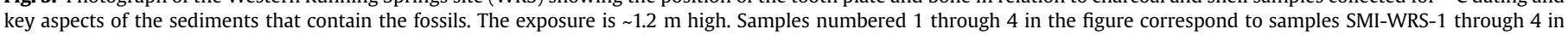
Table 3. In all, the ages of the bone and tooth plate are between 20 and 17 ka. Photographs taken by the authors.

plate and bone fragment were both found in the massive sand and gravel matrix (Fig. $3 \mathrm{f}-\mathrm{g}$ ). We did not observe any distinct strata or soils at this locality.

\subsection{Chronology}

The magnitude of the limestone effect for seven shell samples of modern $H$. ayresiana collected from carbonate substrates on
San Miguel Island (SMI) averages $1360 \pm 270{ }^{14} \mathrm{C}$ years (Table 2). We view this as a worst-case scenario in terms of potential limestone consumption because all of the modern specimens were collected from carbonate-rich areas. This value was used to correct the measured ${ }^{14} \mathrm{C}$ ages of all fossil shells prior to calibration (Table 3). 
Table 2

Limestone effect data for modern specimens of Helminthoglypta ayresiana from San Miguel Island.

\begin{tabular}{|c|c|c|c|c|c|c|c|}
\hline Sample\# & Lab\# & CAMS\# & $\delta^{13} \mathrm{C}(\mathrm{vpdb})$ & Shell $\Delta^{14} \mathrm{C}(\%)$ & Atmos $\Delta^{14} \mathrm{C}(\% 0)$ & Diet $\Delta^{14} C(\% 0)$ & Limestone effect $\left({ }^{14} \mathrm{C} \text { yrs }\right)^{\mathrm{a}}$ \\
\hline SMI-303-1 & WW-9449 & 161894 & -7.5 & $-128.4 \pm 2.5$ & $40 \pm 5$ & $57 \pm 19$ & $1650 \pm 190$ \\
\hline SMI-303-2 & WW-9450 & 161895 & -6.0 & $-75.8 \pm 2.6$ & $40 \pm 5$ & $57 \pm 19$ & $1140 \pm 180$ \\
\hline SMI-309-1 & WW-9451 & 161896 & -8.7 & $-103.0 \pm 2.5$ & $40 \pm 5$ & $57 \pm 19$ & $1400 \pm 190$ \\
\hline SMI-309-2 & WW-9452 & 161897 & -9.2 & $-77.6 \pm 2.6$ & $40 \pm 5$ & $57 \pm 19$ & $1160 \pm 180$ \\
\hline SMI-309-3 & WW-9453 & 161898 & -7.4 & $-91.0 \pm 2.6$ & $40 \pm 5$ & $57 \pm 19$ & $1290 \pm 180$ \\
\hline SMI-327-1 & WW-10083 & 168372 & -6.4 & $-147.3 \pm 2.5$ & $37 \pm 5$ & $53 \pm 18$ & $1800 \pm 180$ \\
\hline SMI-327-2 & WW-10084 & 168373 & -6.1 & $-76.2 \pm 2.9$ & $37 \pm 5$ & $53 \pm 18$ & $1110 \pm 170$ \\
\hline \multicolumn{7}{|c|}{ Average limestone effect } & $1360 \pm 270$ \\
\hline
\end{tabular}

Uncertainties are given at the $1 \sigma(68 \%)$ confidence level.

${ }^{a}$ Based on the difference between the measured shell and modeled dietary ${ }^{14} \mathrm{C}$ activities and converted to ${ }^{14} \mathrm{C}$ yrs (after Pigati et al., 2010 ).

Table 3

Summary of AMS sample information, stratigraphic position, carbon-14 ages, and calibrated ages.

\begin{tabular}{|c|c|c|c|c|c|c|c|c|}
\hline Sample\# & Lab\# & CAMS\# & $\begin{array}{l}\text { Material } \\
\text { dated }^{\mathrm{a}}\end{array}$ & $\begin{array}{l}\text { Stratigraphic } \\
\text { position }\end{array}$ & $\begin{array}{l}\delta^{13} \mathrm{C} \\
\text { (vpdb) }\end{array}$ & $\begin{array}{l}{ }^{14} \mathrm{C} \text { age } \\
(14 \mathrm{C} \text { ka } \mathrm{BP})\end{array}$ & $\begin{array}{l}{ }^{14} \mathrm{C} \text { age corrected for limestone } \\
\text { effect }\left({ }^{14} \mathrm{C} \text { ka BP }\right)^{b}\end{array}$ & $\begin{array}{l}\text { Calibrated age } \\
(\text { cal ka BP })^{\mathrm{c}}\end{array}$ \\
\hline \multicolumn{9}{|c|}{ East Running Springs site $\left(34.04776^{\circ} \mathrm{N}, 120.42339^{\circ} \mathrm{W}\right)$} \\
\hline SMI-323-15 & WW-10082 & 168371 & Shell & Within stratum E & -7.9 & $12.63 \pm 0.03$ & $11.27 \pm 0.27$ & $13.16 \pm 0.47$ \\
\hline SMI-323-4 & WW-10077 & 168366 & Shell & Base of stratum $\mathrm{E}$ & -8.7 & $13.34 \pm 0.04$ & $11.98 \pm 0.27$ & $14.07 \pm 0.80$ \\
\hline SMI-323-2 & WW-10076 & 168365 & Shell & Within stratum D & -7.5 & $17.82 \pm 0.05$ & $16.46 \pm 0.27$ & $19.85 \pm 0.68$ \\
\hline SMI-323-6 & WW-10078 & 168367 & Shell & Base of stratum D & -6.2 & $17.08 \pm 0.05$ & $15.72 \pm 0.27$ & $19.02 \pm 0.62$ \\
\hline SMI-323-7 & WW-10091 & 168380 & Charcoal & Top of stratum C & -26.1 & $19.11 \pm 0.06$ & - & $23.06 \pm 0.27^{\mathrm{d}}$ \\
\hline SMI-323-9 & WW-10079 & 168368 & Shell & Top of stratum B & -7.1 & $17.25 \pm 0.05$ & $15.89 \pm 0.27$ & $19.23 \pm 0.62$ \\
\hline SMI-323-10 & WW-10080 & 168369 & Shell & Top of stratum A & -7.3 & $24.14 \pm 0.10$ & $22.78 \pm 0.29$ & $27.00 \pm 0.60$ \\
\hline SMI-323-11 & WW-10092 & 168381 & Charcoal & Stratum A (paired) & -24.1 & $22.51 \pm 0.08$ & - & $26.83 \pm 0.31$ \\
\hline SMI-323-12 & WW-10081 & 168370 & Shell & Stratum A (paired) & -5.7 & $23.98 \pm 0.10$ & $22.62 \pm 0.29$ & $26.85 \pm 0.61$ \\
\hline \multicolumn{9}{|c|}{ West Running Springs site $\left(34.04536^{\circ} \mathrm{N}, 120.42668^{\circ} \mathrm{W}\right)$} \\
\hline SMI-WRS-2 & WW-10400 & 170609 & Shell & At top of tooth plate & -6.9 & $15.54 \pm 0.04$ & $14.18 \pm 0.27$ & $17.17 \pm 0.74$ \\
\hline SMI-WRS-1 & WW-10415 & 170624 & Charcoal & Just below tooth plate & -24.8 & $15.45 \pm 0.04$ & - & $18.71 \pm 0.10$ \\
\hline SMI-WRS-1 & WW-10416 & 170625 & Humic acids & Just below tooth plate & -24.9 & $14.10 \pm 0.03$ & - & $17.18 \pm 0.19$ \\
\hline SMI-WRS-4 & WW-10419 & 170628 & Humic acids & Even with bone frag & -24.8 & $17.11 \pm 0.04$ & - & $20.64 \pm 0.17$ \\
\hline SMI-WRS-3 & WW-10417 & 170626 & Humic acids & Just below fossils & -23.7 & $18.68 \pm 0.04$ & - & $22.53 \pm 0.14$ \\
\hline
\end{tabular}

Uncertainties for calibrated ages are given at the $2 \sigma(95 \%)$ confidence level. All other uncertainties are given at $1 \sigma(68 \%)$.

a All shells dated by ${ }^{14} \mathrm{C}$ were identified as Helminthoglypta ayresiana.

b For terrestrial gastropod shells only. Accounts for limestone effect of $1360 \pm 270{ }^{14} \mathrm{C}$ yrs (see Table 1).

c Calibrated ages were calculated using CALIB v.7.1html, IntCal13.14C dataset; limit 50.0 calendar ka B.P. Calibrated ages are reported as the midpoint of the calibrated range.

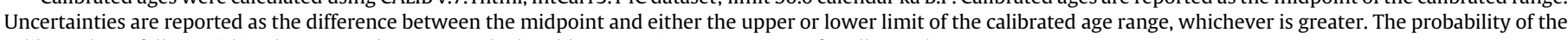
calibrated age falling within the reported range as calculated by CALIB is 0.99 or greater for all samples.

${ }^{\mathrm{d}}$ Charcoal likely reworked from older sediments.

Calibrated ages of charcoal (SMI-323-11; $26.83 \pm 0.31 \mathrm{ka})$ and shell material (SMI-323-12; $26.85 \pm 0.61 \mathrm{ka}$ ) obtained from the same stratigraphic level within stratum A at the ERS site are essentially the same, which suggests that the limestone correction scheme we employed is valid (Table 3 ). In all, nine calibrated ages for the ERS site range from $26.85 \pm 0.61 \mathrm{ka}$ to $13.16 \pm 0.47 \mathrm{ka}$. There is one obvious age reversal, \#SMI-323-7, which was obtained from charcoal in stratum $C$ that appears to have been reworked from older sediments. All other samples maintain stratigraphic order when their associated uncertainties are taken into account (Table 3).

Calibrated ages $(\mathrm{n}=5)$ for the WRS site range from $22.53 \pm 0.14 \mathrm{ka}$ (humic acids) to $17.17 \pm 0.74 \mathrm{ka}$ (shell) (Table 3 ). One of the humic acid ages (\#SMI-WRS-1) is significantly younger than the humin fraction of the same sample, likely because of contamination by younger exogenous materials. This suggests that the oldest two ages (SMI-WRS-4; $20.64 \pm 0.17 \mathrm{ka}$ and SMI-WRS-3; $22.53 \pm 0.14 \mathrm{ka}$ ), which were also obtained from humic acids, may actually be older than reported here. However, we do not have enough data to establish a valid correction factor and, therefore, we take the ages at face value and consider this part of the chronology to be tentative for now.

\section{Discussion}

\subsection{Columbian or pygmy mammoth?}

Thus far, only Columbian and pygmy mammoths have been found on the California Channel Islands (Agenbroad, 2012). The tusk in stratum D at the ERS site is at least $40 \mathrm{~cm}$ in length and $\sim 12 \mathrm{~cm}$ in diameter, which is too large for pygmy mammoths but well within the metric range of Columbian mammoths (Agenbroad, 2001). Thus, we assign it to $M$. columbi. The remaining fossils in stratum $\mathrm{E}$ at the ERS site are also likely mammoth but have not been identified to species. The tooth enamel plate at the WRS site is morphologically unidentifiable beyond Mammuthus sp.

\subsection{Antiquity of the fossils}

Although Columbian mammoths predate pygmy mammoths on the California Channel Islands, and pygmies have been on Santa Rosa Island for at least 80,000 years, the oldest ${ }^{14} \mathrm{C}$ age associated with $M$. columbi fossils on the islands prior to this study is only $17.50 \pm 0.07{ }^{14} \mathrm{C}$ ka (Table 1), which corresponds to a calibrated age of $21.14 \pm 0.26 \mathrm{ka}$ (Agenbroad, 2012). Our results show that 
Columbian mammoths were present on San Miguel Island at $\sim 20 \mathrm{ka}$, similar to the Santa Rosa results. Based on two recent models, relative sea level around San Miguel Island at this time was $\sim 110$ to 100 m below present (Clark et al., 2014; Reeder-Myers et al., 2015). Thus, Santarosae would have existed at its maximum extent and the swimming distance from the mainland would have been at its minimum for the past $\sim 120 \mathrm{ka}$.

These new ages from the Running Springs sites do not necessarily change the way that we view the presence/absence of mammoths on the Channel Islands because we know they inhabited the islands for a long period of time prior to the Last Glacial Maximum (LGM) (Muhs et al., 2015). However, the presence of a Columbian mammoth at 20 ka on San Miguel Island suggests that mammoths likely immigrated to the islands multiple times, including at least once prior to $80 \mathrm{ka}$ and again during the LGM. An alternative scenario is that mammoths only immigrated to the islands once, sometime before $80 \mathrm{ka}$, and some portion of this population gave rise to pygmy mammoths, whereas another portion persisted as a long-lived Columbian mammoth lineage that did not evolve into the dwarf variety. Given the ubiquity of pygmy mammoth bones on the islands that pre-date the LGM (e.g., Agenbroad, 2012), we prefer the former scenario. The former scenario is also consistent with the "dwarfing" process that has long been a tenet of island biogeography (e.g., Palombo and Rozzi, 2013). We note that the competing hypotheses could be tested using aDNA techniques provided the geologic context and age of the fossils analyzed are well understood and the fossils are well preserved.

Our ${ }^{14} \mathrm{C}$ results also show that mammoths were present in the Running Springs area during the late Pleistocene as demonstrated by the fossils in stratum E, which dates to between 14 and $13 \mathrm{ka}$. The interpreted age of these remains further underscores the need for careful excavation and documentation because they occur in stratigraphic units that are very close in age to the earliest known human remains (Arlington Man) on the California Channel Islands (Johnson et al., 2002; Stafford et al., 2008). In such cases, the possibility of human-mammoth interaction, as controversial as it may be, must be taken into consideration and should influence the care with which fossils are recovered.

\subsection{Recommended protocols}

Documentation of the contextual framework of vertebrate fossil localities is critical to the success of future scientific studies. This study, which focuses on the geologic context and stratigraphic position of fossils at sites near Running Springs on San Miguel Island, illustrates the minimum level of detail that should be included in all future studies on the California Channel Islands. The following recommendations are intended to serve as guides to ensure that pertinent information is collected for fossil sites prior to their excavation. Their usage will allow paleontological specimens collected in the future to be accompanied by enough information to permit their use and involvement in scientific studies that employ a wide range of physical, biological, and/or chemical techniques. Future researchers will benefit from the ability to replicate the work and allow them to evaluate site conditions for themselves.

\subsubsection{Location}

Latitude and longitude should be provided in reports to the NPS as Universal Transverse Mercator (UTM) coordinates, decimal degrees (reported to at least four decimal places), or degrees/minutes/ seconds. The geodetic system used should also be reported. If permission from the NPS is obtained, the location information should be reported in the scientific literature.

\subsubsection{Stratigraphic descriptions}

Annotated photographs such as those presented in Figs. 4 and 5 are an ideal way to document the stratigraphy of an outcrop or site, as well as to show exactly where the fossils were obtained within the stratigraphic section. Non-annotated photographs should be accompanied by detailed descriptions of the host sediments (sediment color, grain size, sorting, bedding, etc.) in text form or as a table. If distinct geologic units are present, the descriptions should include the nature of the upper and lower contacts of each unit. We consider that when describing sediments and geological units, it is always better to err on the side of providing too much information than not enough.

\subsubsection{Age control}

The ideal number of age determinations for a given site depends on several factors, including the stratigraphic complexity of the site, the abundance and type of datable material (if any), the nature of the association between the datable material and the fossils, and the availability of funding required to complete the analyses. As stated above, single ages are better than no age control at all, and paired ages are better still in that they allow evaluation of processes (reworking, contamination) that could lead to erroneous interpretations. Multiple paired ages, involving materials from below, within, and above the stratum of interest, are best of all. At the very least, researchers should use geologic maps to provide an age estimate (e.g., Precambrian, Paleozoic, Mesozoic, Cenozoic, Quaternary, Pleistocene, Holocene, etc.) of the unit that contains the fossils.

\subsubsection{Reporting ${ }^{14} \mathrm{C}$ ages}

By convention, the following information should be included when reporting ${ }^{14} \mathrm{C}$ ages in the scientific literature: sample ID number, lab number, type of material dated, $\delta^{13} \mathrm{C}$ value, ${ }^{14} \mathrm{C}$ age and uncertainty level (usually $1 \sigma$ ), limestone correction factor (if applicable), calibrated age (either as a range or the mean of the range) and uncertainty level (preferably $2 \sigma$ ), the calibration dataset used (IntCal13), the program and version used for calibration (e.g., CALIB 7.1.html), and the date when the analysis was done if it differs significantly from the publication date (Stuiver and Polach, 1977). For dating by methods other than ${ }^{14} \mathrm{C}$, researchers should follow established protocols so that enough information is provided to allow the reader to evaluate the accuracy and precision of the ages.

\section{Conclusions}

The discovery of a partial tusk, tooth enamel plate, and several large bones (all likely mammoth) dating to $\sim 20-17$ and $\sim 14-13 \mathrm{ka}$ at sites near Running Springs on San Miguel Island, California, provides an opportunity to discuss the types of information that are required to establish the geologic and stratigraphic context at fossil sites in Channel Islands National Park. Although previous studies have advanced our knowledge of the islands in many ways, the lack of geologic and stratigraphic context information in the published literature has hampered efforts to evaluate the veracity of ${ }^{14} \mathrm{C}$ ages associated with fossils collected from the islands, as well as efforts to reconstruct past environmental conditions. We recommend that future researchers report the following information in the scientific literature: site location as UTM coordinates or latitude/longitude, a detailed description of the host sediments, geologic units present, nature of the unit contacts, age estimate(s) based on chronometric techniques or geologic maps, and, when reporting ${ }^{14} \mathrm{C}$ ages, enough information (AMS number, type of material, $\delta^{13} \mathrm{C}$ value, ${ }^{14} \mathrm{C}$ age and uncertainty, calibration dataset) to allow critical evaluation of the resulting ages. More generally, we hope that this paper will initiate discussion and assist in the formulation of protocols and guidelines 
for future studies conducted on the California Channel Islands in general, and in Channel Islands National Park in particular.

\section{Acknowledgments}

This paper is dedicated to the memories of Larry Agenbroad and Don Johnson, both of whom have had a tremendous impact on our scientific knowledge of the California Channel Islands. Their love of the islands and the mammoths that inhabited them continues to inspire our work. We thank Ian Williams and Kate Faulkner of Channel Islands National Park for logistical and scientific support. This manuscript benefited from constructive reviews from Kathleen Springer, Gene Ellis, Janet Slate, and two anonymous reviewers. This project was funded by the U.S. Geological Survey's Climate and Land Use Change Research and Development Program. Any use of trade, product, or firm names is for descriptive purposes only and does not imply endorsement by the U.S. Government.

\section{References}

Agenbroad, L.D., 1984. New World mammoth distribution. In: Martin, P.L., Klein, R. (Eds.), Quaternary Extinctions: the Search for a Cause. University of Arizona Press, Tucson, AZ, pp. 90-108.

Agenbroad, L.D., 1998. New pygmy mammoth (Mammuthus exilis) localities and radiocarbon dates from San Miguel, Santa Rosa, and Santa Cruz Islands, California. In: Weigand, P. (Ed.), Contributions to the Geology of the Northern Channel Islands, Southern California. Pacific Section of the American Association of Petroleum Geologists, Bakersfield, California, pp. 169-175.

Agenbroad, L.D., 2001. Channel Islands (USA) pygmy mammoths (Mammuthus exilis) compared and contrasted with $M$. columbi, their contintental ancestral stock. In: Cavarretta, G. Gioia, P., Mussi, M., Palombo, M.R. (Eds.), La Terra degli Elefanti/The World of Elephants. Proceedings of the 1st International Congress. Consiglio Nazionale delle Ricerche, Roma, pp. 473-475.

Agenbroad, L.D., 2003. New absolute dates and comparisons for California's Mammuthus exilis. Deinsea 9, 1-16.

Agenbroad, L.D., 2005. North American proboscideans: mammoths: the state of knowledge. Quaternary International 126-128, 73-92.

Agenbroad, L.D., 2012. Giants and pygmies: mammoths of Santa Rosa Island, California (USA). Quaternary International 255, 2-8.

Agenbroad, L.D., Johnson, J.R., Morris, D., Stafford, T.W., 2005. Mammoths and humans as late Pleistocene contemporaries on Santa Rosa Island. In: Garcelon, D.K., Schwemm, C.A. (Eds.), Proceedings of the Sixth California Channel Islands Symposium. Institute for Wildlife Studies, Arcata, California, pp. 3-7.

Agenbroad, L.D., Morris, D., 1999. Giant island/pygmy mammoths: the late Pleistocene prehistory of Channel Islands National Park. In: Santucci, V.L., McClelland, L. (Eds.), National Park Service Paleontological Research 4, Geological Resources Division Technical Report NPS/NRGRD/GRDTR-99/03, pp. 27-31.

Bada, J.L., Schroeder, R.A., Carter, G.F., 1974. New evidence for the antiquity of man in North America deduced from aspartic acid racemization. Science 184, 791-793.

Berger, R., Fergusson, G.J., Libby, W.F., 1965. UCLA radiocarbon dates IV. Radiocarbon 7, 336-371.

Broecker, W., Kulp, J.L., 1957. Lamont natural radiocarbon measurements IV. Science 126, 1324-1334.

Broecker, W., Kulp, L., Tucek, C.S., 1956. Lamont natural radiocarbon measurements III. Science $124,154-165$.

Clark, J., Mitrovica, J.X., Alder, J., 2014. Coastal paleogeography of the CaliforniaOregon-Washington and Bering Sea continental shelves during the latest Pleistocene and Holocene: implications for the archaeological record. Journal of Archaeological Science 52, 12-23.

Crane, H.R., Griffin, J.B., 1958. University of Michigan radiocarbon dates III. Science $128,1117-1123$.

Dibblee Jr., T.W., 2001. Geologic map of San Miguel Island. In: Ehrenspeck, H.E. (Ed.). Dibblee Geological Foundation, Santa Barbara, CA scale 1:24,000.

Erlandson, J.M., Rick, T.C., Largacspada, T., Vellanoweth, R.L., 2004a. CA-SMI-548: a 9500 year old shell midden at Running Springs, San Miguel Island, California. In: Bertrando, E., Levulett, V.A. (Eds.), Emerging from the Ice Age: Early Holocene Occupations on the California Central Coast. San Luis Obispo County Archeological Society, pp. 81-92. Ocassional Paper No. 17.

Erlandson, J.M., Rick, T.C., Vellanoweth, R.L., 2004b. Human impacts on ancient environments: a case study from California's Northern Channel Islands. In: Fitzpatrick, S.M. (Ed.), The Archaeology of Insularity: Examining the Past in Island Environments. Praeger Publishers, New York, NY, pp. 51-83.

Fergusson, G.J., Libby, W.F., 1962. UCLA radiocarbon dates I. Radiocarbon 4, 109-114.

Goodfriend, G.A., Stipp, J.J., 1983. Limestone and the problem of radiocarbon dating of land-snail shell carbonate. Geology 11, 575-577.

Johnson, D.L., 1972. Landscape evolution on San Miguel Island (Ph.D. dissertation). University of Kansas, California.
Johnson, D.L., 1977. The late Quaternary climate of coastal California: evidence for an ice age refugium. Quaternary Research 8, 154-179.

Johnson, D.L., 1978. The origin of island mammoths and the Quaternary land bridge history of the Northern Channel Islands, California. Quaternary Research 10, 204-225.

Johnson, D.L., 1981. More comments on the northern Channel Islands mammoths. Quaternary Research 15, 105-106.

Johnson, D.L., Coleman, D.D., Glassow, M.A., Greenwood, R.S., Walker, P.L., 1980. Late Quaternary environments and events on the California Channel Islands and adjacent mainland. Bulletin of the Ecological Society of America 61, 106-107.

Johnson, J.R., Stafford, T., Ajie, H., Morris, D.P., 2002. Arlington springs revisited. In Browne, D., Mitchell, K., Chaney, H. (Eds.), 5th California Islands Conference. Santa Barbara Museum of Natural History, Santa Barbara, pp. 541-545.

Kalb, J.E., Froehlich, D.J., Bell, G.L., 1996. Phylogeny of African and Eurasian Elephantoidea of the late Neogene. In: Shoshani, J., Tassy, P. (Eds.), The Proboscidea: Evolution and Palaeoecology of Elephants and their Relatives Oxford University Press, pp. 101-116.

Lister, A., Bahn, P., 2007. Mammoths: Giants of the Ice Age. University of California Press, Berkeley, CA.

Lister, A.M., Sher, A.V., 2015. Evolution and dispersal of mammoths across the Northern Hemisphere. Science 350, 805-809.

Lister, A.M., Sher, A.V., van Essen, H., Wei, G., 2005. The pattern and process of mammoth evolution in Eurasia. Quaternary International 126-128, 49-64.

Liu, C., Coleman, D.D., 1981. Illinois state geological survey radiocarbon dates VII. Radiocarbon 23, 352-383.

Madden, C.T., 1981. Origin(s) of mammoths from the Northern Channel Islands, California. Quaternary Research 15, 101-104.

Maglio, V.J., 1973. Origin and evolution of the Elephantidae. Transactions of the American Philosophical Society 63, 1-149.

McDaniel Jr., G.E., Jefferson, G.T., 2006. Mammoths in our midst: the proboscideans of Anza-Borrego Desert State Park ${ }^{\circledR}$, southern Californa, USA. Quaternary International 142-143, 124-129.

Muhs, D.R., Simmons, K.R., Groves, L.T., McGeehin, J.P., Schumann, R.R. Agenbroad, L.D., 2015. Late Quaternary sea-level history and the antiquity of mammoths (Mammuthus exilis and Mammuthus columbi), Channel Islands National Park, California, USA. Quaternary Research 83, 502-521.

Muhs, D.R., Skipp, G., Schumann, R.R., Johnson, D.L., McGeehin, J.P., Beann, J., Freeman, J., Pearce, T.A., Rowland, Z.M., 2009. The origin and paleoclimatic significance of carbonate sand dunes deposited on the California Channel Islands during the last glacial period. In: Damiani, C.C., Garcelon, D.K. (Eds.), Proceedings from the Seventh California Islands Symposium. Institute for Wildlife Studies, Oxnard, CA., pp. 3-14

Orr, P.C., 1956a. Dwarf mammoth and Man on Santa Rosa Island, 26. University of Utah Archeological Papers, pp. 75-81.

Orr, P.C., 1956b. Radiocarbon dates from Santa Rosa Island. Bulletin of the Santa Barbara County Museum of Natural History 2, 1-10.

Orr, P.C., 1960. Radiocarbon dates from Santa Rosa Island II. Bulletin of the Santa Barbara County Museum of Natural History 3, 1-10.

Orr, P.C., 1968. Prehistory of Santa Rosa Island. Santa Barbara Museum of Natural History, Santa Barbara, CA.

Orr, P.C., Berger, R., 1966. The fire areas on Santa Rosa Island, California. Proceedings of the National Academy of Sciences USA 56, 1409-1416.

Palombo, M.R., Rozzi, R., 2013. Dwarfing and gigantism in Quaternary vertebrates In: Elias, S., Mock, C.J. (Eds.), Encyclopedia of Quaternary Science, second ed. pp. 733-747 Amsterdam, Netherlands.

Pigati, J.S., Rech, J.A., Nekola, J.C., 2010. Radiocarbon dating of small terrestrial gastropods in North America. Quaternary Geochronology 5, 519-532.

Reeder-Myers, L, Erlandson, J.M., Muhs, D.R., Rick, T.C, 2015. Sea level, paleogeography, and archeology on California's Northern Channel Islands. Quaternary Research 83, 263-272.

Reimer, P.J., Bard, E., Bayliss, A., Beck, J.W., Blackwell, P.G., Bronk Ramsey, C., Grootes, P.M. Guilderson, T.P., Haflidason, H., Hajdas, I., Hatte, C., Heaton, T.J., Hoffmann, D.L., Hogg, A.G., Hughen, K.A., Kaiser, K.F., Kromer, B., Manning, S.W. Niu, M., Reimer, R.W., Richards, D.A., Scott, E.M., Southon, J.R., Staff, R.A., Turney, C.S.M., van der Plicht, J., 2013. IntCal13 and Marine13 radiocarbon age calibration curves 0-50,000 years cal BP. Radiocarbon 55, 1869-1887.

Roth, V.L., 1993. Dwarfism and variability in the Santa Rosa Island mammoth (Mammuthus exilis): an interspecific comparison of limb-bone sizes and shapes in elephants. In: Hochberg, F.C. (Ed.), Third California Islands Symposium: Recent Advances in Research on the California Islands. Santa Barbara Museum of Natural History, Santa Barbara, CA, pp. 433-442.

Semprebon, G.M., Rivals, F., Fahlke, J.M., Sanders, W.J., Lister, A.M., Gohlich, U.B. 2016. Dietary reconstruction of pygmy mammoths from Santa Rosa Island of California. Quaternary International 406, 123-136.

Springer, K.B., Scott, E., Sagebiel, J.C., Murray, L.K., 2010. Late Pleistocene large mammal faunal dynamics from inland southern California: the Diamond Valley Lake local fauna. Quaternary International 217, 256-265.

Stafford, T.W., Johnson, J.R., West, G.J., 2008. New chronological and geological data from the Arlington Springs site, Seventh California Islands Symposium, Channel Islands National Park, California, p. 73.

Stearns, R.E.C., 1873. No title: paraphrase of comments attributed to Stearns in minutes of Academy's regular meeting. Proceedings of the California Academy of Sciences 5, 152.

Stock, C., Furlong, E.L., 1935. The Pleistocene elephants of Santa Rosa Island, California. Science $68,140-141$ 
Stock, C., Harris, J.M., 1930. Rancho la Brea: A record of Pleistocene life in California, seventh ed. Natural History Museum of Los Angeles County, pp. 1-113. Science Series no. 37.

Stuiver, M., Polach, H.A., 1977. Reporting of ${ }^{14} \mathrm{C}$ data. Radiocarbon 19, 355-363.

Stuiver, M., Reimer, P.J., 1993. Extended ${ }^{14} \mathrm{C}$ database and revised CALIB radiocarbon calibration program. Radiocarbon 35, 215-230.

Webb, S.D., Dudley, J.P., 1995. Proboscidea from the Leisey Shell Pits, Hillsborough County, Florida. Bulletin of the Florida Museum of Natural History 37 (II), 645-660.

Webb, S.D., Morgan, G.S., Hulbert, R.C., Jones, D.S., MacFadden, B.J., Mueller, P.A. 1989. Geochronology of a rich early Pleistocene vertebrate fauna, Leisey Shell Pit, Tampa Bay, Florida. Quaternary Research 32, 96-110.
Wenner, A.M., Cushing, J., Noble, E., Daily, M., 1991. Mammoth radiocarbon dates from the northern Channel Islands, California. Proceedings of the Society for California Archeology 4, 1-6.

Wenner, A.M., Johnson, D.L., 1980. Land vertebrates on the California Channel Islands: sweepstakes or bridges? In: Power, D.M. (Ed.), The California Islands: Proceedings of Multidisciplinary Symposium, Santa Barbara Museum of Natural History, Santa Barbara, California, pp. 497-530.

Zellman, K.L., 2015. Changes in vegetation and biological soil crust communities on sand dunes stabilizing after a century of grazing on San Miguel Island, Channel Islands National Park, California. Monographs of the Western North American Naturalist 7, 225-245. 